\title{
Reverse Mentoring: A Magic Bullet to keep Millennials Engaged at Workplace
}

\author{
${ }^{1}$ Dr. Ruchi Sao, ${ }^{2}$ Prof. Pritam Bhadade \\ ${ }^{1,2}$ Assistant Professor, Shri Ramdeobaba College of Engineering and Management, Nagpur \\ Email:saorn@rknec.edu,bhadadepr1@rknec.edu
}

Received: $20^{\text {th }}$ September 2018, Accepted: $11^{\text {th }}$ October 2018, Published: $31^{\text {st }}$ October 2018

\begin{abstract}
This study is based on secondary data which presents the use of reverse mentoring to keep millennials engaged at the workplace. Mentoring involves a two way communication between people having a work relationship. Mentor in a traditional mentoring system has always been a senior person who would guide the new joiners in their career and goal achievement journey. Today, in every three employees, one employee is a millennial in the workforce. The expectation of millennials from the workplace is completely different from that of the baby boomers who would be retiring in the coming years. However, the millennials have a dynamic thought process, are technologically strong and love to work with autonomy. On the other hand, the baby boomers, generation X and Y are more stable and use only basic technology. Here, comes the role of reverse mentoring with the traditional mentoring process where the juniors who are tech savvy become the mentor for imparting training and knowledge on the continuous use of technology, use of social networking and providing support in the changing business scenario.

Factors responsible for successful reverse mentoring will be discussed in the paper and practices of various companies following reverse mentoring and the challenges while implementing the reverse mentoring system will be presented.
\end{abstract}

\section{Keywords}

Millennials, Multi-Generations, Reverse Mentoring

\section{Introduction}

In majority of the organizations, mentoring is a system imbedded in the organizational structure where the senior assigned as a mentor. In some organizations, the mentoring relationship only stays in files and is never executed for the benefit of the mentee. However, there are companies like Ernst and Young who have a dedicated mentoring system across all locations which focus on the development of mentee which is a combination of more informal reviews and discussions which are developmental in nature. Mentoring requires a lot of time and may take away some good amount of productive time of both the parties involved in the process of mentoring.

In the traditional system of mentoring, the duo always comprised of a senior leader and younger executive for guidance in a formal and informal way.

Mentors have rich experience and exposure to the business. This can be easily shared with the juniors to develop them as future business leaders. At times, it may get difficult for the mentors to take out time from their schedule for mentoring. Fast changing technology has resulted into acquisition of new skills at the workplace for all the employees. Here comes the role of reverse mentoring wherein the mentees come in the role of mentor and help the seniors learn new processes and adapt to the changes in technology. The new generation is energetic and always looks for challenging roles. They are not of those typical kind of employees who can take instructions and work. They want autonomy and are smart workers as compared to the senior cadre.

The term reverse mentoring was first coined by Jack Welch, CEO of General Electric (GE) in 1999 with the objective to train the old employees on internet. Around 500 top executives reached out to people for the same including Jack Welch. After the success of reverse mentoring at GE, many companies started this practice where the millennials and elders started working on projects where former had more energy and hands on technology and the latter had stability and more experience. Reverse mentoring seems to be picking up with the increasingly fast pace of technology in business. 
The best part about a reverse or reciprocal mentoring is that it can be executed in the existing structure of company mentoring programs. The only thing required is to bridge the gap between employees of different a generation and encourage them to meet regularly to share their knowledge. This process does not require new setup or infrastructure to be built. The relationship between mentor and mentee in reverse mentoring should not be restricted to people of same gender or similar background because a person can learn many other things from person who is different from him/her.

The employees belonging to the age bracket of around 21 to 35 have got a huge potential which just needs to be channelized in the right direction. These age groups had exposure to technology since a long time and are well versed with various changes that have happened over a period of time. This can be coupled with skills and knowledge of the seniors. Together, this blend of knowledgeable seniors and tech savvy employees are perfect for the functioning of mentoring. It is like merging knowledge with technology which is the need of hour.

With respect to employee engagement, majority of the millennials today want to prove themselves at the workplace and dream of becoming a CEO at the age of 30 or even less than that. But the question is, are the millennials ready to be the next generation leader at such a young age? Probably, the answer is yes which means the millennials if are engaged towards their job and the organization then the leadership traits can be inherited from senior and learnt over a period of time. Reverse mentoring can help bridge that gap.

\section{Material and Methods}

The study is exploratory in nature and is completely based on secondary data published in magazines and company websites. This paper attempts to collate the work of various HR practitioners. The practices in the field of reverse mentoring is discussed in the result and discussion part of the paper. Reverse mentoring as a concept was into inception form more than a decade but had gained momentum when a lot of articles were published post 1999 after GE Company had initiated the concept and practice of reverse mentoring in their organization.

Numerous companies have taken initiatives for encouraging the employees to work and perform better. However, the need of the organization today is to divert their focus on more engaged employees and those who are ready to go the extra mile in the company towards their job, department and the organization. Reverse mentoring is a form of initiative that can be taken by the organizations to help retention of millennial generation. The result and discussion part would discuss the various initiatives taken by the companies.

\section{Results and Discussion}

The point needs to be understood that it is not possible for reverse mentoring to work alone. Mentoring and reverse mentoring will always go hand in hand. Technology is the only thing that is changing every moment today. Reverse mentoring in case of technology will surely continue to be used as the need for changes in technology in all sectors is quite evident today. Right from engineering to medical sciences to use to data analytics; everything has seen a sea change in these years. Reverse mentoring is seen as a powerful alliance between the seniors and juniors. The junior employees have often been seen as those who would make move in their jobs quite frequently for a little increment or a better working environment. Given the situation, if the leader ensure engagement of millennials at workplace through various ways, it would surely help the millennials to not only stay engaged but on a broader objective stay retained in the organization.

Following the footsteps of GE, companies like Credit Suisse, ABB and many more companies have also initiated reverse mentoring.

This part of the paper would discuss the various initiatives taken by companies for reverse mentoring.

\section{Keeping Millennials Engaged at Workplace}

Following are the various ways in which millennials are kept engaged at workplace by involving them in the process of reverse mentoring. The further part will give inputs with respect to best practices in reverse mentoring done by various companies. There are many more practices undertaken in the company out of which few have been reported. 
- Reverse mentoring also helped in improving interpersonal relationship between senior and junior by bridging the gap.

- Sanjay Kapoor, Airtel CEO introduced the concept in 2008. They started with around 20 pairs and interactions were on latest gadgets, opportunities and new technology. The mentees had an employee age of around 2 to 3 years. Airtel also launched a campaign by the name 'Rock on' to make the seniors aware about technological advancements.

- Millennials also help to seniors understand the issues on cultural diversity

- Many seniors have started reading and even writing blogs and started using mobile apps which was not used earlier.

- Don Baer had an opportunity to receive mentoring from many seniors till his age of 60 today. Majority of the mentoring sessions post his 45 years of age has been for reverse mentoring. While sharing his experiences at AARP, The Magazine; he took inputs from juniors as to what is new on social media and understanding the use of various applications on his iPhone. For the first time when Baer heard about the concept of reverse mentoring, he himself wanted to have one reverse mentor. So, he selected a junior of 32 years of age to act as a mentor.

- Companies all over the world are seeing reverse mentoring as more than an interaction between baby boomers and millennials. They are seeing it in the form of exchange of knowledge, experiences and exposures in order to have more gain to both the generations.

- It is not necessary that reverse mentoring will happen only in case of technological knowledge sharing. For instance, in the field of engineering and medical science there is a scope for use of robotics and other aspects which can be used more proficiently by the millennials who have learnt and worked on a lot of live projects in the organizations.

- Many organizations have come with the idea of making pairs and teams for mentoring. The idea is to understand the use of technology, social media and other data analytics methods from the millennials in a much better way with the seniors.

- For instance, PWC Company makes mentors to those employees who had joined the company in their early 20 's of age. They have seen the company and their department grow. So, after a couple of years they are selected to act as mentors. In cases of reverse mentoring, it happens informally at a wide scale.

- In September 2013, Ryan Ellis published an article in Association of Talent Development Magazine. She opined how the millennials should be allowed to lead the way with the help of back up support and coaching. Cross generational knowledge transfer is of utmost value to the organization.

\section{Conclusion}

Reverse mentoring can help the seniors gain more energy and learn to reduce work by smart use of technology and at the same time millennials can stay more engaged with a feeling that they are contributing towards the success of their seniors and organization.

There is a need for seniors to understand the importance of reverse mentoring from the point of view of development. Sometimes, the seniors may have a fixed perception and a block with respect to seniority in terms of age or experience. However, as discussed in the paper, the good sign is as to how the seniors are taking the advantage of reverse mentoring for their own development. Some seniors from the baby boomer have also reported that it is fun as the same thing has decreased the emotional generation gap between their child and them. Reverse mentoring would surely go a long way in the organizations and is not a practice which would fade away.

The future scope of study can be where reverse mentoring policies can be formulated by researchers for companies. The relationship of reverse mentoring can be checked with employee satisfaction as well. Study of perception can also be undertaken for both the generations; baby boomers and millennials. This study would be useful to understand the openness to the concept and practice of reverse mentoring for multi generations. 


\section{References}

1. Utku GÜĞERÇİN, "Leveraging the differences: a case of reverse mentoring", Proceedings of the $11^{\text {th }}$ International Management Conference "The role of management in the economic paradigm of the $\mathrm{XXI}^{\mathrm{st}}$ century" November 2nd-4th, 2017, Bucharest, Romania

2. https://www.aarp.org/work/on-the-job/info-2015/on-the-job-mentoring.html

3. https:/www.morningfuture.com/en/article/2017/07/19/reverse-mentoring-the-alliance-between-juniors-andseniors/38/

4. https:/www.td.org/magazines/td-magazine/reverse-mentoring-letting-millennials-lead-the-way 